\title{
Hubungan pemberian ASI eksklusif dibanding susu formula dengan angka kejadian diare
}

\author{
${ }^{1}$ Esther Boas, ${ }^{1}$ Meiyati Panambunan, ${ }^{2}$ Odi R. Pinontoan \\ ${ }^{1}$ Puskesmas Likupang Minahasa Utara Sulawesi Utara Indonesia
${ }^{2}$ Pascasarjana Universitas Sam Ratulangi Manado
Email: dr.adejn@gmail.com
}

Abstract: This study was aimed to determine the relationship between exclusive breastfeeding compared to formula milk and diarrhea incidence in Likupang health center, North Sulawesi. This was a cross-sectional design study with a sample size of 88 infants. Information was obtained through interviews and questionnaires to the infants' mothers. Univariat data were presented in distribution frequency table form and bivariate analysis data were analyzed by using chi square test. The results showed that there was a significant relationship between exclusive breastfeeding compared to formula milk and the incidence of diarrhea in infants under 1 year. Infant with exclusive breastfeeding had significantly lower incidence of diarrhea than those with formula milk (Sig 0.003). Conclusion: The incidence of diarrhea was lower among infants with exclusive breast feeding compared to infants with formula milk.

Keywords: diarrhea, exclusive breastfeeding

\begin{abstract}
Abstrak: Penelitian ini bertujuan mengetahui hubungan pemberian ASI eksklusif dibanding susu formula terhadap angka kejadian diare di puskesmas Likupang, Sulawesi Utara. Penelitian ini merupakan studi potong lintang dengan besar sampel 88 bayi. Informasi didapatkan melalui wawancara dan kuesioner kepada ibu dari bayi yang diteliti. Data univariat ditampilkan dalam bentuk tabel distribusi frekuensi dan analisis bivariat data dilakukan dengan menggunakan uji Chi square. Hasil penelitian menunjukkan bahwa terdapat hubungan bermakna antara pemberian asi eksklusif dibanding susu formula dengan angka kejadian diare pada anak berusia dibawah 1 tahun. Bayi dengan pemberian ASI eksklusif secara signifikan memiliki angka kejadian diare yang lebih rendah daripada bayi dengan pemberian susu formula (sig. 0,003). Simpulan: Kejadian diare lebih rendah pada bayi dengan ASI eksklusif dibandingkan bayi dengan susu formula.
\end{abstract}

Kata kunci: diare, ASI eksklusif

Insidensi diare di Indonesia masih didominasi oleh kelompok usia kurang dari 1 tahun. Prevalensi diare tahun 2013 di Indonesia ialah 7,0. Kelompok usia kurang dari 1 tahun memiliki prevalensi terbesar diikuti kelompok usia 1-4 tahun sebesar 6,7. ${ }^{1}$ Rotavirus diketahui sebagai penyebab utama diare pada anak berkontribusi untuk kematian 215.000 anak pada tahun $2013 .^{2}$

Vaksin oral untuk rotavirus pertama kali diperkenalkan pada tahun 2013 di Inggris dengan merek dagang Rotarix ${ }^{\circledR}{ }^{3}$
Efikasi vaksin ini telah teruji efektif dalam menurunkan angka kejadian diare pada anak. $^{4} \quad$ Keberhasilan ini membuat WHO menyarankan pemberian vaksin rotavirus dalam program vaksin nasional. ${ }^{5}$ Vaksin rotavirus diberikan sejak bulan ke-6 dan diulangi setiap tahun. ${ }^{6}$ Satu kali penyuntikan di Inggris memerlukan biaya dasar 24 Euro yang senilai Rp. 359.978. Harga vaksin ini dikatakan cukup efisien dalam hal biaya di Negara Turki. ${ }^{8}$ Salah satu toko online di Indonesia menjual 
vaksin ini seharga Rp. 491.500. ${ }^{9}$ Vaksin ini juga hanya berhubungan dengan salah satu penyebab diare akut yaitu infeksi rotavirus.

Di sisi lain ASI eksklusif memiliki banyak keunggulan, salah satunya ialah meningkatkan sistem kekebalan tubuh. ASI eksklusif menurunkan risiko berbagai macam penyakit seperti otitis media, infeksi saluran pernafasan atas, dan diare. ${ }^{10}$ Keunggulan ASI eksklusif ini kemudian disambut oleh pemerintah dalam bentuk peraturan pemerintah (PP) nomor 33 tahun 2012 tentang pemberian ASI eksklusif. Pembentukan PP ini sebagai tindak lanjut dari Undang-Undang (UU) nomor 36 tahun 2009 pasal 129 ayat (2). ${ }^{11,12}$

ASI eksklusif ini masih memiliki kendala dalam hal aplikasinya. Sebuah penelitian menemukan bahwa pengetahuan ibu, informasi petugas kesehatan, dukungan orang terdekat, dan promosi susu formula berhubungan dengan pilihan ibu untuk memberikan susu formula kepada bayinya. ${ }^{13}$ Temuan manfaat ASI eksklusif diharapkan meningkatkan minat ibu dalam memberikan ASI eksklusif kepada bayinya.

Penelitian ini bertujuan untuk mengetahui hubungan pemberian ASI eksklusif dibanding susu formula terhadap angka kejadian diare di puskesmas Likupang, Sulawesi Utara.

\section{METODE PENELITIAN}

Penelitian ini dilakukan di Puskesmas Likupang, Sulawesi Utara. Besar sampel yang didapatkan sebanyak 88 bayi. Kriteria inklusi ialah bayi berusia kurang dari 12 bulan yang berkunjung ke wilayah kerja Puskesmas Likupang. Kriteria eksklusi ialah bayi yang menderita sakit berat atau diare kronis, bayi dengan berat badan lahir rendah, dan riwayat lahir kurang dari 37 minggu.

Diare akut adalah suatu penyakit yang ditandai frekuensi buang air besar lebih dari 4 kali sehari dengan konsistensi cair dan berlangsung kurang dari 14 hari. ${ }^{14}$ ASI eksklusif adalah pemberian ASI tanpa tambahan makanan atau cairan lainnya sampai usia 6 bulan. ${ }^{15}$

Informasi didapatkan melalui wawancara dan kuesioner kepada ibu dari bayi yang diteliti.

Data univariat ditampilkan dalam bentuk tabel distribusi frekuensi dan analisis bivariat data dilakukan dengan menggunakan uji chi square.

\section{HASIL PENELITIAN}

Subjek yang memenuhi kriteria penelitian sebanyak 88 bayi. Usia ibu minimal ialah 14 tahun dan usia ibu maksimal ialah 40 tahun, dengan rerata usia 26,9 tahun, nilai median 26 tahun, dan nilai modus 25 (SD 6,499) tahun. Rentang usia ibu terbanyak ialah 21-30 tahun yaitu sebanyak 44 orang $(50,1 \%)$ diikuti usia 31 40 sebanyak 27 orang $(30,6 \%)$. Pendidikan terakhir ibu didominasi oleh SMA yaitu sebanyak 40 orang $(45,5 \%)$ diikuti SMP sebanyak 30 orang $(34,1 \%)$.

Usia bayi minimal ialah 1 bulan dan usia bayi maksimal ialah 12 bulan dengan rerata usia 8,95 bulan, nilai median 9 bulan dan nilai modus 6 bulan. Rentang usia bayi terbanyak ialah 9-12 bulan yaitu sebanyak 54 bayi (17\%) diikuti usia 5-8 bulan sebanyak 33 bayi (16\%) dan usia 1-4 bulan sebanyak 1 bayi $(1,1 \%)$. Jenis kelamin bayi didominasi oleh perempuan yaitu sebanyak 55 bayi $(62,5 \%)$ (Tabel 1$)$.

Pengumpulan data dalam bentuk tabel silang menunjukkan bahwa kelompok yang paling banyak ialah kelompok yang diberi ASI eksklusif dan tidak diare yaitu berjumlah 38 orang $(43,2 \%)$. Kelompok yang paling sedikit ialah yang diberi ASI eksklusif dan diare yaitu berjumlah 12 orang $(13,6 \%)$. Hasil perhitungan expected count untuk semua kelompok berada diatas 5 (Tabel 2).

Hasil anaslisis bivariat data dengan menggunakan Chi Square didapatkan hubungan yang signifikan $(\mathrm{p}=0,003)$ antara pemberian asi eksklusif dibanding susu formula dengan angka kejadian diare (Tabel 3). 
Tabel 1. Karakteristik subjek penelitian

\begin{tabular}{lcc}
\hline \multicolumn{1}{c}{ Keterangan } & Jumlah & Persentase \\
\hline Rentang usia ibu & & \\
$14-20$ & 17 & 19,3 \\
$21-30$ & 44 & 50,1 \\
$31-40$ & 27 & 30,6 \\
Total & 88 & 100 \\
Pendidikan ibu & & \\
SD & 15 & 17 \\
SMP & 30 & 34,1 \\
SMA & 40 & 45,5 \\
D3 & 1 & 1,1 \\
S1 keatas & 2 & 2,3 \\
Total & 88 & 100 \\
Usia bayi & & \\
1-4 & 1 & 1,1 \\
5-8 & 33 & 16 \\
9-12 & 54 & 17 \\
Jenis kelamin bayi & & \\
Laki- laki & 33 & 37,5 \\
Perempuan & 55 & 62,5 \\
Total & 88 & 100 \\
\hline
\end{tabular}

Tabel 2. Tabel silang data penelitian

\begin{tabular}{llccc}
\hline & & Diare & Tidak diare & Total \\
\hline Asi eksklusif & Count & 12 & 38 & 50 \\
& Expected Count & 18,8 & 31,3 & 50 \\
& \% of Total & $13,6 \%$ & $43,2 \%$ & $56,8 \%$ \\
Susu formula & Count & 21 & 17 & 38 \\
& Expected Count & 14,3 & 23,8 & 38 \\
& \% of Total & $23,9 \%$ & $19,3 \%$ & $43,2 \%$ \\
Total & Count & 33 & 55 & 88 \\
& Expected Count & 33 & 55 & 88 \\
& \% of Total & $37,5 \%$ & $62,5 \%$ & $100.00 \%$ \\
\hline
\end{tabular}

Tabel 3. Hasil Uji Chi Square

\begin{tabular}{llll}
\hline & Value & Df & $\begin{array}{l}\text { Asymp, Sig, } \\
\text { (2-sided) }\end{array}$ \\
\hline $\begin{array}{l}\text { Pearson } \\
\text { Chi-Square }\end{array}$ & 9,004 & 1 & 0,003 \\
\hline
\end{tabular}




\section{BAHASAN}

Usia ibu dalam penelitian ini cukup menarik dimana usia minimal masih berada di bawah usia yang digariskan oleh Undang -Undang Republik Indonesia Nomor 1 Tahun 1974 tentang perkawinan pasal 7 di mana dikatakan "Perkawinan hanya diizinkan bila pihak pria mencapai umur 19 (sembilan belas) tahun dan pihak wanita sudah mencapai usia 16 (enam belas) tahun." "Sebuah penelitian di Amerika melaporkan bahwa hubungan seks pada remaja di Amerika didominasi oleh usia 17 -19 tahun. Usia seks aktif bagi remaja di Amerika d ibawah 12 tahun dikatakan sangat jarang, kira-kira 1/10.000 anak. Rata-rata anak Amerika yang berusia 15 tahun sudah menggunakan pil kontrasepsi. ${ }^{16}$ Pada penelitian ini, data usia ibu yaitu saat mengantarkan anaknya ke puskesmas; berarti kemungkinan ibu dengan usia minimal dalam penelitian ini sudah melahirkan anak pada usia $\leq 14$ tahun. Usia ibu hamil sangat menentukan risiko kehamilan. ${ }^{17}$

Pendidikan terakhir ibu didominasi oleh SMA yaitu sebanyak 40 orang $(45,5 \%)$ diikuti SMP sebanyak 30 orang $(34,1 \%)$. Pendidikan ibu di beberapa daerah tidak memiliki hubungan dengan pemberian ASI eksklusif pada bayi. ${ }^{18}$, Penelitian dari beberapa daerah melaporkan bahwa pengetahuan ibu mengenai ASI eksklusif berhubungan dengan pemberian ASI eksklusif. ${ }^{19-22}$ Peran serta bidan dan petugas kesehatan penting dalam meningkatkan pengetahuan ibu mengenai pentingnya ASI eksklusif. ${ }^{23,24}$

Hasil analisis bivariat data dengan menggunakan Chi Square mendapatkan hubungan bermakna $(P=0,003)$ antara pemberian asi eksklusif dibanding susu formula dengan angka kejadian diare. Sebanyak 12 bayi $(13,6 \%)$ yang diberi asi dan mengalami diare dibandingkan 21 bayi $(23,90 \%)$ yang diberi susu formula dan mengalami diare. Relative risk pada penelitian ini ialah 0,434 yang berarti penggunaan susu formula berisiko 0,434 kali lebih besar terhadap kejadian diare.

Risiko diare dalam pemberian susu formula yang lebih tinggi dibandingkan ASI dapat disebabkan oleh beberapa hal. Susu formula lebih mudah terkontaminasi dengan bakteri. Kontaminasi ini dapat terjadi sejak proses pembuatan susu di pabrik atau setelah susu formula diproses untuk diberikan kepada bayi. Bakteri Cronobacter yang dulunya disebut Enterobacter Sakazaki dapat hidup di makanan kering seperti susu formula kemudian menyebabkan infeksi dimulai dari infeksi ringan seperti diare maupun infeksi yang lebih serius seperti peradangan selaput otak (meningitis). ${ }^{25}$ Bakteri ini tidak dapat dimatikan dengan pasteurisasi sederhana. Beberapa metode baru pasteurisasi seperti High Hydrostatic Pressure Processing (HPP), metode ultrasound, radiasi gamma dan elektron, dan cahaya ultraviolet masih belum bisa memastikan keamanan dari konsumsi susu formula. $^{26}$

Kejadian diare setelah penggunaan susu formula juga dapat diakibatkan karena intoleransi laktosa, yaitu kurangnya enzim laktase di dalam usus untuk mencerna gula dalam susu yaitu laktosa. ${ }^{27}$ Laktosa $^{2}$ merupakan disakarida yang banyak pada susu mamalia. Laktosa seharusnya dihidrolisis di vili usus halus dengan bantuan laktase menjadi glukosa dan galaktosa. Laktase paling banyak terdapat pada periode perinatal. Sekitar $75 \%$ penduduk dunia mengalami pengurangan laktase yang bervariasi setelah usia 2-12 tahun. Kelompok yang tidak mengalami pengurangan laktase termasuk kedalam kelompok lactase persistence. ${ }^{28}$ Intoleransi laktosa tidak eksklusif dialami oleh penderita lactose intolerance. Sebuah penelitian melaporkan 3 dari 100 orang dewasa normal menunjukkan gejala lactose intolerance pada pemberian laktosa sebanyak $10 \mathrm{~g} .{ }^{29}$

Pilihan ibu untuk tidak memberikan ASI eksklusif kepada bayinya dipengaruhi oleh banyak faktor. Wawancara pada 50 ibu di China merangkumkan alasan pokok ibu memberikan susu formula kepada anaknya antara lain kurangnya pengetahuan mengenai keuntungan dari ASI dan edukasi 
antenatal yang kurang. ${ }^{30}$ Hal ini sangat disayangkan mengingat keuntungan jangka panjang dari ASI eksklusif yang berdampak besar terhadap kualitas hidup dan tentunya ekonomi keluarga. ${ }^{31,32}$ Keuntungan ini antara lain: mengurangi risiko obesitas dan diabetes, meningkatkan intelejensi anak, mengurangi perdarahan postpartum, mengembalikan berat badan ibu lebih cepat, mencegah kanker ovarium dan payudara, serta mengurangi risiko osteoporosis. $^{30,33}$ Hasil penelitian ini diharapkan dapat meningkatkan pengetahuan dan motivasi dalam meningkatkan perilaku pemberian ASI eksklusif dari ibu kepada bayi.

\section{SIMPULAN}

Dari hasil penelitian dan bahasan dapat disimpulkan bahwa terdapat hubungan bermakna antara pemberian asi eksklusif dibanding susu formula dengan angka kejadian diare pada bayi berusia di bawah 1 tahun.

\section{DAFTAR PUSTAKA}

1. Kementerian kesehatan RI. Riset kesehatan dasar (RISKESDAS) tahun 2013. Badan Penelitian dan Pengembangan Kesehatan. 2013; p. 74.

2. Tate JE, Burton AH, Boschi-Pinto C, Parashar UD, Agocs M, Serhan F, de Oliveira L, et al. Global, regional, and national estimates of rotavirus mortality in children $<5$ years of age, 2000-2013. Clin Infect Dis. 2016 1;62(suppl 2):S96-105.

3. Atchison CJ, Stowe J, Andrews N, Collins S, Allen DJ, Nawaz S, et al. Rapid declines in age group-specific Rotavirus infection and acute gastroenteritis among vaccinated and unvaccinated individuals within 1 year of Rotavirus vaccine introduction in England and Wales. J Infect Dis. 2016 Jan 15;213(2):243-9.

4. Lamberti LM, Ashraf S, Walker CL, Black RE. A systematic review of the effect of Rotavirus vaccination on diarrhea outcomes among children younger than 5 years. Pediatr Infect Dis J. 2016;35(9):992-8.

5. Rotavirus vaccines: an update. Wkly
Epidemiol Rec. 2009; 84:533-40.

6. Ikatan Dokter Anak Indonesia. Jadwal imunisasi anak umur 0-18 tahun. [cited 2016 Jun 7]. Available from: http://www.idai.or.id/wp-content/ uploads/2014/04/Jadwal-Imunisasi2014-lanscape-Final.pdf

7. Hansen EC, Fiem E, de Blasio BF, Salamanca BV. Is ongoing rotavirus vaccination in Norway cost-effective? London: 16th Biennial European Conference, 2016 June 13.

8. Koksal T, Akelma AZ, Koksal AO, Kutukoglu I, Ozdemir O, Yuksel CN, et al. Cost-effectiveness of rotavirus vaccination in Turkey. $\mathbf{J}$ Microbiol Immunol Infect. 2016. pii: S168411829(16)30026-3. Doi: 10.1016/j.jmii.2016.03.005.

9. Prosehat [internet]. Jual paket vaksinasi Rotavirus Rotarix (1X Suntik) 2016. [cited 2016 Jun 7]. Available from: https://www.prosehat.com/produk/vaksi nasi/rotavirus-1-X-suntik-rotarix

10. Eidelman AI, Schanler RJ, Johnston M, Landers S, Noble L, Szucs K, et al. Breastfeeding and the use of human milk. Pediatrics. 2012;129(3):e827-41.

11. Presiden Republik Indonesia. UndangUndang Republik Indonesia Nomor 36 tahun 2009 tentang kesehatan. 2009.

12. Kementerian Kesehatan Republik Indonesia. Peraturan Pemerintah Republik Indonesia Nomor 33 tahun 2012 tentang pemberian air susu ibu eksklusif. 2012.

13. Susanto H, Wilar R, Lestari H. Faktorfaktor yang mempengaruhi pemberian susu formula pada bayi yang dirawat di ruang nifas RSUP Prof. Dr. R. D. Kandou Manado. e-CliniC. 2015;3(1).

14. Bishop WP, Ebach DR. The digestive system. In: Marcdante KJ, Kliegman RM, editors. Nelson: Essentials of pediatric (7th ed). Philadelphia: Elsevier Saunders, 2015; p. 417-81.

15. Presiden Republik Indonesia. UndangUndang Republik Indonesia nomor 1 tahun 1974 tentang perkawinan. 1974.

16. Finer LB, Philbin JM. Sexual initiation, contraceptive use, and pregnancy among young adolescents. Pediatrics. 2013;131(5):886-91.

17. Cohen WR. Does maternal age affect pregnancy outcome? BJOG. 
2014;121(3):252-4.

18. Oktoviyanda VD, Ropi H, Mardiyah A. Hubungan tingkat pendidikan, pekerjaan, dan paritas ibu dengan usia penyapihan pada balita. Jurnal Keperawatan Padjadjaran. 2013;1(3).

19. Sartono A, Utaminingrum $H$. Hubungan pengetahuan ibu, pendidikan ibu dan dukungan suami dengan praktek pemberian Asi eksklusif di Kelurahan Muktiharjo Kidul Kecamatan Telogosari Kota Semarang. Jurnal Gizi. 2012;1(1).

20. Widiyanto S, Aviyanti D. Hubungan pendidikan dan pengetahuan ibu tentang ASI eksklusif dengan sikap terhadap pemberian ASI eksklusif. Jurnal Kedokteran Muhammadiyah. 2012;1(1).

21. Aprilia G. Hubungan tingkat pengetahuan ibu tentang Asi eksklusif dengan pemberian Asi eksklusif di Desa Harjobinangun Purworejo. Jurnal Komunikasi Kesehatan (Edisi 5) P3M Akbid Purworejo. 2012;3(2).

22. Sriningsih I. Faktor demografi, pengetahuan ibu tentang Air Susu Ibu dan pemberian ASI eksklusif. Kemas. 2011;6(2):100-6.

23. Setiawati E, Mukhtar M, Maslani $N$. Hubungan sikap dan peran bidan terhadap program pemberian asi eksklusif di wilayah kerja puskesmas jambu burung kabupaten banjar tahun 2014. Jurnal Skala Kesehatan. 2016;6(1).

24. Raharjo BB. Profil ibu dan peran bidan dalam praktik inisiasi menyusu dini dan asi eksklusi. Kemas. 2014;10(1):53-63.

25. Yan QQ, Condell O, Power K, Butler F, Tall BD, Fanning S. Cronobacter species (formerly known as Enterobacter sakazakii) in powdered infant formula: a review of our current understanding of the biology of this bacterium. J Appl Microbiol.
2012;113(1):1-5.

26. Pina-Pérez MC, Rodrigo D, Martínez A. Non-thermal inactivation of Cronobacter Sakazakii in infant formula milk: a review. Crit Rev Food Sci Nutr. 2014. doi:10.1080/10408398.2013.781991.

27. Misselwitz B, Pohl D, Frühauf H, Fried M, Vavricka SR, Fox M. Lactose malabsorption and intolerance: pathogenesis, diagnosis and treatment. United European Gastroenterol J. 2013;1(3):151-9.

28. Mattar R, de Campos Mazo DF, Carrilho FJ. Lactose intolerance: diagnosis, genetic, and clinical factors. Clin Exp Gastroenterol. 2012;5:113-21.

29. Yang J, Deng Y, Chu H, Cong Y, Zhao J, Pohl D, et, al. Prevalence and presentation of lactose intolerance and effects on dairy product intake in healthy subjects and patients with irritable bowel syndrome. Clin Gastroenterol Hepatol. 2013;11(3):262-8.

30. Zhang K, Tang L, Wang H, Qiu LQ, Binns CW, Lee AH. Why do mothers of young infants choose to formula feed in china? Perceptions of mothers and hospital staff. Int J Environ Res Public Health. 2015;12(5):4520-32.

31. Walters D, Horton S, Siregar AY, Pitriyan P, Hajeebhoy N, Mathisen $\mathbf{R}$, et al. The cost of not breastfeeding in Southeast Asia. Health Policy and Planning. 2016;Apr 23:1-10. Doi: 10.1093/heapol/czw044.

32. Ma P, Brewer-Asling M, Magnus JH. A case study on the economic impact of optimal breastfeeding. Matern Child Health J. 2013;17(1):9-13.

33. Kanazawa S. Breastfeeding is positively associated with child intelligence even net of parental IQ. Dev Psychol. 2015;51(12):1683. 